\title{
Future therapeutic targets in rheumatoid arthritis?
}

\author{
Tommy Tsang Cheung ${ }^{1}$ - Iain B. McInnes ${ }^{2}$
}

Received: 16 March 2017 / Accepted: 29 March 2017 / Published online: 27 April 2017

(C) The Author(s) 2017. This article is an open access publication

\begin{abstract}
Rheumatoid arthritis (RA) is a chronic inflammatory disease characterized by persistent joint inflammation. Without adequate treatment, patients with RA will develop joint deformity and progressive functional impairment. With the implementation of treat-to-target strategies and availability of biologic therapies, the outcomes for patients with RA have significantly improved. However, the unmet need in the treatment of RA remains high as some patients do not respond sufficiently to the currently available agents, remission is not always achieved and refractory disease is not uncommon. With better understanding of the pathophysiology of RA, new therapeutic approaches are emerging. Apart from more selective Janus kinase inhibition, there is a great interest in the granulocyte macrophage-colony stimulating factor pathway, Bruton's tyrosine kinase pathway, phosphoinositide-3-kinase pathway, neural stimulation and dendritic cell-based therapeutics. In this review, we will discuss the therapeutic potential of these novel approaches.
\end{abstract}

Keywords Rheumatoid arthritis · GM-CSF · JAK · BTK · PI3K · Tolerogenic dendritic cells

This article is a contribution to the special issue on Immunopathology of Rheumatoid Arthritis - Guest Editors: Cem Gabay and Paul Hasler

Iain B. McInnes

Iain.McInnes@glasgow.ac.uk

1 Department of Medicine, Li Ka Shing Faculty of Medicine, Queen Mary Hospital, The University of Hong Kong, 102 Pokfulam Road, Hong Kong, Hong Kong

2 Institute of Infection, Immunity and Inflammation, University of Glasgow, B4/13, GBRC, 120 University Place, Glasgow G12 8TA, UK

\section{Introduction}

Rheumatoid arthritis is a chronic inflammatory disease characterized by persistent joint inflammation. Without adequate treatment, patients with rheumatoid arthritis (RA) will develop joint deformity and progressive functional impairment. Substantial evidence indicates that persistent systemic inflammation and immune dysfunction plays a major role in the development of co-morbidities, such as cardiovascular diseases, osteoporosis, interstitial lung disease and malignancies. Large retrospective cohorts have shown that the risk of myocardial infarction is at least 1.5 times higher compared with controls $[1,2]$ and patients with RA have increased cardiovascular mortality as a result [3-5]. In addition, many studies consistently indicate an increase in the incidence of malignancies, such as lymphoma [6-8]. As a result, patients with RA have reduced quality of life and life expectancy.

With the implementation of treat-to-target strategies, the outcomes of patients with RA have significantly improved. The likelihoods of achieving remission and low disease activity are significantly higher compared with usual care and historical controls. As a result, those patients experience less functional impairment [9-15]. Strategic approaches of this nature not only alleviate clinical symptoms of RA but also demonstrate significant benefits to RA-associated co-morbidities. Osteoporosis is significantly less frequent in patients with disease remission, and a similar trend was also observed for cardiovascular disease [16]. Patients in remission have a significant reduction in cardiovascular risk that is comparable to that of healthy controls [17].

In parallel, biologic therapies have revolutionized the treatment paradigm of RA because they are generally more effective than conventional synthetic disease-modifying anti-rheumatic drugs (csDMARDs). Even biologic therapies currently available only demonstrate clinical efficacy in about two thirds of patients. As a result, the unmet need in the treatment 
of RA remains high, remission rates are insufficient and new therapeutic approaches should be explored especially for those patients with refractory disease. In this review, we will discuss the potentials of several novel therapeutic agents.

\section{Extracellular target in RA}

A range of extracellular targets are currently under consideration. The majority concern previously targeted cytokines, e.g. IL-6R or ligands, IL-6. Recent studies targeting a variety of cytokines, e.g. IL-17, IL-20 and IL-21, have been disappointing [18-24]. Herein, we will focus on one novel cytokine that has elicited promising data in early trials.

\section{Granulocyte macrophage-colony stimulating factor}

Granulocyte macrophage-colony stimulating factor (GM$\mathrm{CSF}$ ) is a haematopoietic growth factor responsible for the differentiation and proliferation of myeloid cells, including neutrophils, dendritic cells and macrophages. In addition, GM-CSF also induces migration and proliferation of endothelial cells [25]. It is produced by a wide variety of cell types, such as myeloid cells, lymphocytes and tissueresident cells including chondrocytes, fibroblasts, osteoblast and endothelial cells [26, 27]. Production of GMCSF can be stimulated by multiple agents, such as lipopolysaccharide, tumour necrosis factor, IL-1 and IL-23 [28]. It binds to a heterodimeric GM-CSF receptor, which consists of a ligand-specific binding $\alpha$-chain and a signal transducing $\beta$-chain [29]. Subsequent signalling from the GM-CSF receptor activates Janus kinase-signal transducer and activator of transcription (JAK-STAT), phosphoinositide-3-kinase (PI3K) and MAPK pathway $[30,31]$.

GM-CSF plays a crucial role in innate immune responses. In general, it enhances the effector functions of neutrophils and macrophages, leading to increased expression of adhesion molecules, production of inflammatory cytokines and activation of phagocytosis [32]. GM-CSF can also polarize macrophages into an inflammatory M1 phenotype, which are involved in synovial inflammation [33]. GM-CSF is also involved in the development, maturation, antigen presentation and cytokine production by dendritic cells [34-36]. Several in vitro studies show that GM-CSF stimulates the development of inflammatory dendritic cells. These inflammatory dendritic cells produce pro-inflammatory cytokines, such as TNF, IL-12 and IL-23. Following antigen engagement and conditioning by the pro-inflammatory cytokines, the inflammatory dendritic cells are able to present self-antigens and stimulate $\mathrm{T}$ cell in the lymph nodes $[37,38]$.
In patients with RA, GM-CSF is expressed in the synovial membrane and the level of GM-CSF is increased in the synovial fluid [39]. Increased expression of GM-CSF receptors is found on circulating monocytes [40], which promotes the subsequent maturation and activation of macrophages in the synovium. In addition, GM-CSF receptors are up-regulated in the synovial tissue [41], and in vitro studies show that GM-CSF induces the proliferation of fibroblast-like synoviocytes [42]. GM-CSF also contributes to the differentiation and survival of Th17 cells and dendritic cells [43]. In the presence of GMCSF, monocyte-derived dendritic cells maintain their inflammatory potential and are resistant to the immunosuppressive effect of IL-10 in vitro [44]. These dendritic cells also produce high levels of IL-1, IL- 6 and TNF- $\alpha$ [45] and are able to present auto-antigens via MHC molecules, contributing to the pathogenesis of RA [46].

Based on these findings, GM-CSF inhibition is an attractive therapeutic target for RA. In animal models, administration of GM-CSF exacerbates arthritis in the collagen-induced arthritis (CIA) model, while administration of neutralizing antibodies against GM-CSF prevents disease progression $[47,48]$. In view of the robust effects of GM-CSF inhibition demonstrated in pre-clinical studies, the efficacy of GM-CSF inhibitors has been evaluated in clinical trials [49].

Mavrilimumab is a monoclonal antibody against the human GM-CSF receptor alpha chain. In the EARTH EXPLORER I study, 326 patients with active RA and who had previously an inadequate response to DMARDs were randomized to receive different doses of mavrilimumab versus placebo. In this phase IIb study, a greater proportion of patients receiving mavrilimumab achieved $\mathrm{a} \geq 1.2$ decrease in disease activity score (DAS)28-CRP from baseline and the 100-mg dose demonstrated a significant effect versus placebo (23.1 vs. $6.7 \%$ ). Besides, patients receiving mavrilimumab achieved higher American College of Rheumatology (ACR) response rates at week 24 (ACR20-69.2 vs. $40.0 \%$, $p=0.005$; ACR $50-30.8$ vs. $12.0 \%, p=0.021$; ACR7017.9 vs. $4.0 \%, p=0.030$ ). Adverse events were generally mild or moderate in intensity. No significant hypersensitivity reactions, serious or opportunistic infections, or changes in pulmonary parameters were observed [50]. In the EARTH EXPLORER II study, 138 patients with active RA and had an inadequate response to tumour necrosis factor inhibitors were randomized to receive mavrilimumab $100 \mathrm{mg}$ every 2 weeks or golimumab $50 \mathrm{mg}$ every 4 weeks for 24 weeks. The difference in the numbers of patients achieving ACR20 response was not statistically different between groups (65.6 vs. $62 \%, p=0.666$ ) (NCT01715896). As a result, further large-scale studies are warranted to confirm the therapeutic potential of mavrilimumab and to determine its optimal position in the treatment algorithm of RA. 


\section{Intracellular targets in RA}

\section{Janus kinase-signal transducer and activator of transcription pathway}

JAK is a receptor tyrosine kinase that mediates intracellular signalling through the transcription factor STAT. In humans, the JAK-STAT pathway is the principal signalling cascade for a wide variety of cytokines and growth factors [51-54]. Intracellular activation of JAK occurs when ligand binding induces the crosslinking of receptor subunits. Activated JAKs phosphorylate the tyrosine residues on the receptors, allowing the binding of STATs in the SRC2 homology domain. JAK then phosphorylates the tyrosine residues on the STATs, leading to dimerization and activation of the STATs. Activated STATs then migrate via the cytoplasm to translocate into the nucleus, where they induce transcription of target genes [54].

The JAK family comprises four members, JAK1, JAK2, JAK3 and Tyk2. JAK1, JAK2 and Tyk2 are expressed ubiquitously, while JAK3 has limited expression in haematopoietic cells [55]. JAK1 interacts with a wide variety of cytokines, through the common $\gamma$ chain receptor subunit (IL-2 and IL-4 receptor family) and the glycoprotein-130 subunit. JAK1 is also involved in type 1 interferon signal transduction. JAK2 also interacts with cytokines through the glycoprotein-130 subunits, as well as other hormones including erythropoietin, thrombopoietin, prolactin and growth hormone. As a result, the use of JAK2 inhibitors may be associated with anaemia and thrombocytopenia. JAK3 interacts with many inflammatory cytokines through the common $\gamma$ chain receptor subunit [56], and inactivating mutations in the common $\gamma$ chain and JAK3 have been shown to cause X-linked severe combined immunodeficiency [57]. Patients with Xlinked severe combined immunodeficiency have a significantly impaired adaptive immune system due to the absence $\mathrm{T}$ cells and non-functional B cells (Table 1).

Many JAK inhibitors have been studied for the treatment of RA [58]. Tofacitinib, the first-in-class JAK inhibitor, has been shown to be efficacious in different clinical settings - it blocks JAK1 and JAK3 preferentially [59-64] (Table 2). In the ORAL standard trial, patients with an inadequate response to methotrexate were randomized to receive tofacitinib, adalimumab or placebo plus background methotrexate. At 6 months, patients receiving tofacitinib (5 or $10 \mathrm{mg}$ twice daily) and adalimumab $40 \mathrm{mg}$ every 2 weeks achieved higher ACR20 response rates $(51.5,52.6$ and $47.2 \%$, respectively), compared with those receiving placebo $(28.3 \%)$. There were also greater reductions in the Health Assessment Questionnaire Disability Index (HAQ-DI) scores at 3 months and higher percentages of patients achieving DAS remission at 6 months [62]. In the ORAL scan trial, patients receiving tofacitinib (5 or $10 \mathrm{mg}$ twice daily) had less radiological progression. The mean changes in total modified Sharp score for tofacitinib at 5 and $10 \mathrm{mg}$ twice daily were 0.12 and 0.06 , respectively, versus 0.47 for placebo [60]. Patients with inadequate response to tumour necrosis factor inhibitors were evaluated in the ORAL step trial. The addition of tofacitinib (5 or $10 \mathrm{mg}$ twice daily) to methotrexate (MTX), compared with placebo plus MTX, resulted in significantly higher ACR20 response rates (42, 48 vs. $24 \%$, respectively) and greater reductions in the HAQDI scores at 3 months [61].

The relative safety of tofacitinib has generally appeared similar to that of biologic DMARDs, including increased risk of infections and liver function derangements, cytopenias, hyperlipidaemia and, possibly, increased serum creatinine levels. Gastrointestinal perforations have also been reported. The incidence was similar to the published data of tumour necrosis factor inhibitors and perhaps lower than that associated with tocilizumab. It has been postulated that this potential side effect could be due to a significant inhibition of IL-6 production. The risk of herpes zoster reactivation was found to be significantly increased in patients receiving tofacitinib. Data from the phase II, III and longterm extension studies showed that the incidence rate of herpes zoster reactivation was 4.4 per 100 patient-years in patients receiving tofacitinib, compared to 1.5 per patient-years in the placebo arm. The risk is substantially higher among Asians, the elderly and those using higher doses of glucocorticoids [65].

Baricitinib, another novel JAK inhibitor, has also been evaluated in several phase III clinical trials. It preferentially inhibits JAK1 and JAK2 and demonstrates efficacy in patients with RA in different clinical settings [66-69] (Table 3). In the RA-BEAM trial, patients with active RA on background MTX were randomized to receive baricitinib $4 \mathrm{mg}$ daily, adalimumab $40 \mathrm{mg}$ every 2 weeks or placebo (switched to baricitinib at week 24) for 52 weeks. At week 12, patients receiving baricitinib were more likely to achieve ACR20 response compared with those receiving adalimumab or placebo (70 vs. 61 vs. $40 \%$ ). The ACR20 response rates at week 12 in patients receiving $4 \mathrm{mg}$ baricitinib and placebo were 70 and $40 \%$, respectively. There were also greater reductions in the HAQ-DI scores and progression of mean total modified Sharp scores at 24 weeks [69]. Similar results were also demonstrated in the RA-BUILD trial. Patients with active RA and who had an inadequate response to conventional synthetic DMARDs were randomized to receive baricitinib (2 or $4 \mathrm{mg}$ daily) or placebo. Patients receiving $4 \mathrm{mg}$ baricitinib achieved higher ACR20 response rates than those receiving placebo at 12 weeks [66]. In addition, patients who had an inadequate response to tumour necrosis factor inhibitors also showed a significant improvement after receiving high-dose baricitinib. The ACR20 response rates at week 12 in patients receiving 
Table 1 Cytokines and hormones activating the JAK pathway

\begin{tabular}{|c|c|c|}
\hline JAK1 & JAK2 & JAK3 \\
\hline Common $\gamma$ chain receptor family & & Common $\gamma$ chain receptor family \\
\hline IL-2, IL-4, IL-7, IL-9, IL-15, IL-21 & & IL-2, IL-4, IL-7, IL-9, IL-15, IL-21 \\
\hline Gp130 receptor family & Gp130 receptor family & \\
\hline $\begin{array}{l}\text { IL-6, IL-11, IL-27, IL-31 } \\
\text { Interferon }\end{array}$ & $\begin{array}{l}\text { IL-6, IL-11, IL-27, IL-31 } \\
\text { Interferon }\end{array}$ & \\
\hline \multirow[t]{6}{*}{$\operatorname{IFN} \alpha / \beta / \gamma$} & $\begin{array}{l}\text { IFN } \alpha / \beta / \gamma \\
\text { Hormones }\end{array}$ & \\
\hline & Erythropoietin & \\
\hline & Thrombopoietin & \\
\hline & Prolactin & \\
\hline & $\begin{array}{l}\text { Growth hormone } \\
\text { GM-CSF receptor family }\end{array}$ & \\
\hline & IL-3R, IL-5R, GM-CSF-R & \\
\hline
\end{tabular}

$4 \mathrm{mg}$ baricitinib and placebo were 55 and $27 \%$, respectively [67]. To date, baricitinib is pending approval by the FDA and EMA.

Meanwhile, other JAK inhibitors are being evaluated in phase III clinical trials. Filgotinib developed by Galapagos NV/Gilead and ABT-494 by AbbVie are both selective JAK1 inhibitors. The use of these agents can theoretically reduce the risk of JAK2- and JAK3-associated adverse reactions. Both filgotinib and ABT-494 showed promising results in patients with RA in phase IIb studies [70-73], and phase III studies are being conducted to evaluate their therapeutic efficacies (Table 4).

\section{Bruton's tyrosine kinase pathway}

Bruton's tyrosine kinase (BTK) is another key intracellular kinase being actively investigated for the treatment of RA in addition to other immune-mediated disorders, e.g. SLE. It is a member of the Tec family of non-receptor tyrosine kinases with restricted expression in B cells and myeloid cells, such as

Table 2 Clinical trials of tofacitinib

\begin{tabular}{|c|c|c|c|c|c|}
\hline Study name & $\begin{array}{l}\text { Number of } \\
\text { subjects }\end{array}$ & $\begin{array}{l}\text { Subject } \\
\text { characteristics }\end{array}$ & Intervention & Primary endpoints & Results \\
\hline ORAL start [59] & 958 & MTX naive & $\begin{array}{l}\text { Tofacitinib ( } 5 \text { or } 10 \mathrm{mg}) \text { vs. } \\
\text { MTX } 20 \mathrm{mg} \text { per week }\end{array}$ & $\begin{array}{l}\text { ACR } 70 \text { response } \\
\text { Mean change in modified } \\
\text { total Sharp score }\end{array}$ & $\begin{array}{l}25.5,37.7 \text { vs. } 12.0 \% \\
0.2,<0.1 \text { vs. } 0.8\end{array}$ \\
\hline ORAL scan [60] & 797 & MTX-IR & Tofacitinib (5 or $10 \mathrm{mg}$ ) vs. placebo & $\begin{array}{l}\text { ACR20 response } \\
\text { Mean change in modified } \\
\text { total Sharp score } \\
\text { Mean change in HAQ-DI } \\
\text { DAS remission }\end{array}$ & $\begin{array}{l}51.5,61.8 \text { vs. } 25.3 \% \\
0.12,0.06 \text { vs. } 0.47^{\mathrm{a}} \\
-0.40,-0.54 \text { vs. }-0.15 \\
7.2,16 \text { vs. } 1.6 \%\end{array}$ \\
\hline ORAL solo [63] & 611 & DMARD-IR* & Tofacitinib ( 5 or $10 \mathrm{mg}$ ) vs. placebo & $\begin{array}{l}\text { ACR20 response } \\
\text { Mean change in HAQ-DI } \\
\text { DAS remission }\end{array}$ & $\begin{array}{l}59.8,65.7 \text { vs. } 26.7 \% \\
-0.50,-0.57 \text { vs. }-0.19 \\
5.6,8.7 \text { vs. } 4.4 \% \text { (NS) }\end{array}$ \\
\hline ORAL sync [64] & 792 & DMARD-IR* & Tofacitinib ( 5 or $10 \mathrm{mg}$ ) vs. placebo & $\begin{array}{l}\text { ACR20 response } \\
\text { Mean change in HAQ-DI } \\
\text { DAS remission }\end{array}$ & $\begin{array}{l}52.1,56.6 \text { vs. } 30.8 \% \\
-0.44,-0.53 \text { vs. }-0.16 \\
8.5,12.5 \text { vs. } 2.6 \%\end{array}$ \\
\hline ORAL standard [62] & 717 & MTX-IR & $\begin{array}{l}\text { Tofacitinib ( } 5 \text { or } 10 \mathrm{mg} \text { ) vs. } \\
\quad \text { adalimumab } 40 \mathrm{mg} \mathrm{q} 2 \mathrm{w} \text { vs. placebo }\end{array}$ & $\begin{array}{l}\text { ACR20 response } \\
\text { Mean change in HAQ-DI } \\
\text { DAS remission }\end{array}$ & $\begin{array}{l}51.5,52.6,47.2 \text { vs. } 28.3 \% \\
0.55,-0.61,0.49 \text { vs. }-0.24 \\
6.2,12.5,6.7 \text { vs. } 1.1 \%\end{array}$ \\
\hline ORAL step [61] & 399 & TNFi-IR & Tofacitinib ( 5 or $10 \mathrm{mg}$ ) vs. placebo & $\begin{array}{l}\text { ACR20 response } \\
\text { Mean change in HAQ-DI } \\
\text { DAS remission }\end{array}$ & $\begin{array}{l}41.7,48.1 \text { vs. } 24.4 \% \\
-0.43,-0.46 \text { vs. }-0.18 \\
6.7,8.8 \text { vs. } 1.7 \%\end{array}$ \\
\hline
\end{tabular}

*At least 1 non-biologic or biologic DMARD\#262

${ }^{a}$ Since tofacitinib $5 \mathrm{mg}$ twice daily failed to show statistically significance for radiographic progression, and due to the step-down procedure applied to the primary efficacy endpoints, significance was not declared for the HAQ-DI and DAS remission 
Table 3 Clinical trial of baricitinib

\begin{tabular}{|c|c|c|c|c|c|}
\hline Study name & $\begin{array}{l}\text { Number of } \\
\text { subjects }\end{array}$ & $\begin{array}{l}\text { Subject } \\
\text { characteristics }\end{array}$ & Intervention & Primary endpoints & Results \\
\hline $\begin{array}{c}\text { RA-BEGIN } \\
{[68]}\end{array}$ & 588 & DMARD naive & $\begin{array}{l}\text { Baricitinib } 4 \mathrm{mg}+\text { MTX } \\
\text { 10-20 mg per week vs. } \\
\text { baricitinib } 4 \mathrm{mg} \text { vs. } \\
\text { MTX } 10-20 \mathrm{mg} \text { per week }\end{array}$ & ACR20 response & 77 vs. $62 \%^{\mathrm{a}}$ \\
\hline RA-BEAM [69] & 1307 & MTX-IR & $\begin{array}{l}\text { Baricitinib } 4 \mathrm{mg} \text { vs. adalimumab } \\
40 \mathrm{mg} \mathrm{q} 2 \mathrm{w} \text { vs. placebo }\end{array}$ & ACR20 response & 70 vs. 61 vs. $40 \%^{b}$ \\
\hline RA-BUILD [66] & 684 & DMARD-IR & Baricitinib ( 2 or $4 \mathrm{mg}$ ) vs. placebo & ACR20 response & 62 vs. $39 \%^{\mathrm{c}}$ \\
\hline RA-BEACON [67] & 527 & TNFi-IR & Baricitinib (2 or $4 \mathrm{mg}$ ) vs. placebo & ACR20 response & 55 vs. $27 \%^{\mathrm{c}}$ \\
\hline RA-BEYOND & Estimated 3073 & & Baricitinib (2 or $4 \mathrm{mg}$ ) & $\begin{array}{l}1 \text { drug-related adverse event } \\
\text { or any serious adverse events }\end{array}$ & Ongoing \\
\hline
\end{tabular}

${ }^{a}$ The primary endpoint is a non-inferiority comparison of baricitinib monotherapy to MTX monotherapy

${ }^{b}$ The primary endpoint is a superiority comparison of baricitinib therapy to placebo. Baricitinib therapy is compared with adalimumab based on noninferiority design

${ }^{\mathrm{c}}$ The primary endpoint is the comparison between baricitinib $4 \mathrm{mg}$ and placebo

macrophages and dendritic cells [74]. It plays a crucial role in B cell development and activation. When an antigen binds to the $\mathrm{B}$ cell receptor, spleen tyrosine kinase (SYK) is activated and leads to subsequent phosphorylation of adaptor proteins recruiting PI3K to the plasma membrane. As a result, intracellular levels of phosphatidylinositol-3,4,5-triphosphate (PIP3) increases [75]. PIP3 binds to the pleckstrin homology domain of BTK and thereby promotes the recruitment of BTK to the plasma membrane [76]. Subsequent phosphorylation of BTK by the Srckinases and SYK activates phospholipase $\mathrm{C}-\gamma 2$, which leads to nuclear factor $\mathrm{KB}$ and nuclear factor of activated T cells transcriptional activation [77]. Through these signalling pathways, BTK activation induces B cell survival, proliferation and differentiation into plasma cell. Mutations of the BTK genes are associated with the development of X-linked agammaglobulinaemia in human and X-linked immunodeficiency in mice $[78,79]$. In addition to B cell receptor signalling, BTK is also associated with macrophage signalling through the $\mathrm{FC} \gamma$ receptors. In the absence of BTK, $\mathrm{FC} \gamma$ receptor-associated functions are impaired. In animal models, macrophages from mice with X-linked immunodeficiency produce less nitric oxide, TNF- $\alpha$ and IL-I $\beta[80,81]$.

Given that BTK is functionally active in both B cells and myeloid cell function, it is an attractive therapeutic target for RA. In particular, inhibiting the kinase activity of BTK would block multiple signalling pathways in different cell populations. In the CIA model, mice with mutations in BTK have decreased susceptibility to develop arthritis [82]. Similarly, FC $\gamma$ receptordeficient mice do not develop arthritis, even with the presence of auto-antibodies [83]. Consequently, several small molecule BTK inhibitors have been developed and demonstrated efficacy in animal models of RA [84]. However, only six BTK inhibitors are currently reported to be in clinical development for RA. All of the inhibitors selectively target the ATP-binding pocket of BTK, and the irreversible inhibitors covalently bind the cysteine residue in the active site of the kinase domain [85].

CC-292 is the first irreversible BTK inhibitor that has been evaluated in a phase II study. Forty-seven patients with active RA and had an inadequate response to methotrexate were

Table 4 Clinical trials of filgotinib and ABT-494

\begin{tabular}{|c|c|c|c|c|c|}
\hline Study drug & Estimated enrolment & Subject characteristics & Intervention & Primary endpoints & ClinivalTrials.gov identifier \\
\hline \multirow[t]{3}{*}{ Filgotinib } & 1200 & MTX naive & $\begin{array}{l}\text { Filgotinib + MTX vs. } \\
\text { filgotinib vs. MTX }\end{array}$ & ACR20 response & NCT02886728 \\
\hline & 1650 & MTX-IR & $\begin{array}{l}\text { Filgotinib vs. adalimumab } \\
\text { vs. placebo }\end{array}$ & ACR20 response & NCT02889796 \\
\hline & 423 & bDMARD-IR & Filgotinib vs. placebo & ACR20 response & NCT02873936 \\
\hline \multirow[t]{4}{*}{ ABT-494 } & 975 & MTX naive & ABT-494 vs. MTX & $\begin{array}{l}\text { ACR50 response; } \\
\text { DAS28-CRP remission }\end{array}$ & NCT02706873 \\
\hline & 1500 & MTX-IR & $\begin{array}{l}\text { ABT- } 494 \text { vs. adalimumab } \\
\text { vs. placebo }\end{array}$ & ACR20 response & NCT02629159 \\
\hline & 600 & MTX-IR & ABT-494 vs. MTX & $\begin{array}{l}\text { ACR20 response; } \\
\text { DAS28-CRP LDA }\end{array}$ & NCT02706951 \\
\hline & 600 & csDMARD-IR & ABT-494 vs. placebo & $\begin{array}{l}\text { ACR20 response; } \\
\text { DAS28-CRP LDA }\end{array}$ & NCT02675426 \\
\hline
\end{tabular}


randomized to receive either CC-292 $375 \mathrm{mg}$ daily versus placebo. The primary endpoint was the ACR 20 response at 4 weeks. The study was completed in March 2016 but the results have not been published so far (NCT01975610). Other potential BTK inhibitors are still being investigated in preclinical or early phase clinical studies. The phase I study on HM71224 (NCT01765478), developed by Hamni, has just been completed, while the phase I study on TK-020 (NCT02413255), developed by Takeda, is still ongoing [86].

\section{Phosphoinositide-3-kinase pathway}

PI3Ks are lipid-signalling kinases that phosphorylate phosphoinositides to produce phosphorylated inositol lipids. PI3Ks are classified into class I, II and III according to their structures, regulations and lipid substrate specificities [87, 88]. To date, only the functions of class I PI3Ks have been well characterized, whereas the roles of class II and III PI3Ks in humans are yet to be elucidated. Class I PI3Ks, which include $\mathrm{PI} 3 \mathrm{~K} \alpha, \mathrm{PI} 3 \mathrm{~K} \beta, \mathrm{PI} 3 \mathrm{~K} \delta$ and $\mathrm{PI} 3 \mathrm{~K} \gamma$, catalyze the phosphorylation of phosphatidylinositol-4,5-bisphosphate to phosphatidylinositol-3,4,5-trisphosphate (Table 5). Through subsequent signalling cascades, class I PI3Ks control many cellular functions, such as growth, proliferation, survival and apoptosis, as well as leukocyte adhesion and migration. PI3K $\alpha$ and $\mathrm{PI} 3 \mathrm{~K} \beta$ are ubiquitously expressed, whereas $\mathrm{PI} 3 \mathrm{~K} \delta$ and $\mathrm{PI} 3 \mathrm{~K} \gamma$ are preferentially expressed in leukocytes and play a crucial role in innate and adaptive immune response.

In T cells, class I PI3Ks are activated by T cell receptor (TCR) or IL-2 receptor engagement. In p110 $\gamma$ knockout T cells, TCRmediated early signalling is relatively unaffected, but they proliferate less after stimulation with CD3-specific antibody and produce lower levels of cytokines in vitro [89]. Similarly, PI3K $\delta$ kinase inactive knockin mice also show reduced $\mathrm{T}$ cell proliferation and activation in vitro, and impaired antigen-specific $\mathrm{T}$ cell responses in vivo [90]. In addition, PI3K $\delta$ is involved in the differentiation of $\mathrm{T}$ cells. In animal models, $\mathrm{p} 110 \delta$ mutant mice had impaired differentiation along the T helper (Th) 1 and Th 2 lineage [91] and exhibited a significant decrease in T helper 2 cytokine responses [92]. P1108 mutant mice also had reduced regulatory $\mathrm{T}$ cell (Treg) populations in the spleen and lymph nodes, implicating PI3K $\delta$ in the maintenance of Treg in the periphery. Moreover, Treg cells with inactive PI $3 \mathrm{~K} \delta$ had attenuated secretion of IL-10 to suppress T cell proliferation in vitro [93].

$\mathrm{PI} 3 \mathrm{~K} \delta$ is essential for B cell development and function as it generates survival signals even without antigen binding to the B cell receptors [94-96]. In animal models, PI3K $\delta$ mutant mice have significant reductions in the IgM producing $\mathrm{B}$ cell and marginal zone B cell populations [96]. B cell proliferative responses to IL-4 stimulation and T cell-independent antibody responses in PI3K $\delta$ mutant mice are also attenuated [97, 98]. Furthermore, B cells deficient in p1108 showed diminished chemotactic responses to CXCL13 and CXCR5-dependent B cell homing to Peyer's patches [99].

In common with other leucocytes, class I PI3Ks are markedly enriched in neutrophils. In p110 $\gamma$ knockout mice, neutrophils migrate less efficiently towards chemokines and chemoattractants, such as complement C5a and bacterial peptide Nformyl-methionyl-leucyl-pehnylalamine (fMLP) [100, 101]. Neutrophils with inactive p110 $\gamma$ also demonstrated impaired reactive oxygen species production [101] and neutrophil respiratory burst in response to fMLP [102]. Apart from neutrophils, dendritic cells from p110 $\gamma$ knockout mice also developed impaired migration to the site of inflammation [103]. Although the involvement of PI $3 \mathrm{~K} \delta$ in neutrophil functions has been controversial, $\mathrm{PI} 3 \mathrm{~K} \delta$ may have a role in promoting IL- 6 release in response to cKit stimulation on dendritic cells [104].

Based on these findings, $\mathrm{PI} 3 \mathrm{~K} \delta$ and $\mathrm{PI} 3 \mathrm{~K} \gamma$ have attracted considerable interest as pharmacological targets in the treatment of RA [105, 106]. In the CIA model, mice treated with a p110 $\gamma$ selective inhibitor show significant reduction in joint inflammation. Histological measures of synovial inflammation and neutrophil infiltration in arthritic joints are also significantly attenuated [107]. PI3K $\gamma$ is also implicated in the regulation of synovial fibroblasts, in which p110 $\gamma$ deficiency leads to a milder inflammatory-erosive arthritis and TNFmediated cartilage destruction through reduced expression of matrix metalloproteinases in fibroblasts and chondrocytes. In vitro analyses confirmed that the decreased invasiveness of fibroblasts is mediated by reduced phosphorylation of Akt and extracellular signal-regulated kinase. Similar findings using a PI3K $\gamma$-specific inhibitor in human synovial

Table 5 Isoforms of PI3K

\begin{tabular}{|c|c|c|c|c|c|}
\hline & $\mathrm{PI} 3 \mathrm{~K}$ isoform & Catalytic subunit & Regulatory subunits & Substrate & Product \\
\hline \multirow[t]{3}{*}{ Class IA } & $\mathrm{PI} 3 \mathrm{~K} \alpha$ & $\mathrm{p} 110 \alpha$ & $\mathrm{p} 85 \alpha, \mathrm{p} 85 \beta, \mathrm{p} 55 \alpha, \mathrm{p} 55 \gamma, \mathrm{p} 50 \alpha$ & PI-4,5-P2 & PIP3 \\
\hline & $\mathrm{PI} 3 \mathrm{~K} \beta$ & $\mathrm{p} 110 \beta$ & & & \\
\hline & $\mathrm{PI} 3 \mathrm{~K} \delta$ & $\mathrm{p} 110 \delta$ & & & \\
\hline Class IB & $\mathrm{PI} 3 \mathrm{~K} \gamma$ & p110y & p101, p84 & PI-4,5-P2 & PIP3 \\
\hline \multirow[t]{3}{*}{ Class II } & & PIK3-C2 & & PI-4-P & PI-3,4P2 \\
\hline & & PIK3-C3 & & PI & PI-3-P \\
\hline & & PIK3-C2 & & & \\
\hline Class III & & VPS34 & $\mathrm{P} 150$ & PI & PI-3-P \\
\hline
\end{tabular}


fibroblasts from patients with RA who exhibit disease-specific up-regulation of $\mathrm{PI} 3 \mathrm{~K} \gamma$ was also confirmed in this study [108]. A recent study also reported the role of PI3K signalling pathway in synovial angiogenesis in the CIA model. Hypoxiainducible factor $1 \alpha$ and vascular endothelial growth factor are up-regulated through PI3K signalling and mediates subsequent neovascularization of the synovium [109].

At present, PI3K inhibition is a major focus in the field of oncology. Idelalisib, the first-in-class PI3K inhibitor, appears efficacious in refractory chronic lymphocytic leukaemia and indolent non-Hodgkin's lymphoma and has provided some safety data concerning PI3K inhibition [110-113]. Many pharmaceutical companies are exploring the potential of PI3K inhibitors in autoimmune diseases, like RA. However, no PI3K inhibitor has yet entered a clinical development programme to our knowledge.

\section{Neuropathways in RA}

The reciprocal effects of the nervous system on immunity has raised recent interest. It is well known that the nervous system regulates inflammation through peripheral nerves and a variety of neurotransmitters and neuropeptides. In animal models, peripheral denervation attenuates joint inflammation in mice with adjuvant induced arthritis [114]. An imbalance of the autonomic nervous system has been implicated in many inflammatory conditions. In general, activation of para-sympathetic nervous system mediates an anti-inflammatory response, while the sympathetic nervous system may have both pro-inflammatory and anti-inflammatory properties [115]. The para-sympathetic nervous system, through the vagus nerve, exerts anti-inflammatory actions. In a mouse model, electrical stimulation of the peripheral part of the vagus nerve significantly decreases serum $\mathrm{TNF}-\alpha$ levels in rats with bilateral cervical vagotomy. In vitro studies showed that acetylcholine (ACh) inhibits proinflammatory cytokine release by the macrophages in a dose dependent fashion [116]. Subsequent research had identified the neuronal type $\alpha 7-\mathrm{ACh}$ receptor subtype as the essential regulator of the anti-inflammatory effects mediated by the para-sympathetic nervous system [117]. $\alpha 7$-ACh receptors are not only found on neurons but also widely expressed in immune cells and fibroblast like synoviocytes [118-120]. In the CIA model, administration of a specific $\alpha 7$-ACh receptor agonist showed effective attenuation of arthritis and systemic inflammatory responses $[121,122]$. Conversely, $\alpha 7$-ACh receptor knockout mice developed more severe arthritis compared with the wild type controls [123]. Apart from the effects mediated by immune cells, activation of the $\alpha 7-\mathrm{ACh}$ receptor in the fibroblast like synoviocytes also suppresses the production of pro-inflammatory cytokines [119, 124]. The spleen also plays an important role in the regulation of systemic inflammation. Although there is no evidence showing that lymphoid organs are directly innervated by the para-sympathetic innervation, studies have shown that the spleen is able to receive signals from the para-sympathetic system and vagus nerve activation may inhibit TNF- $\alpha$ production by splenic macrophages via the celiac superior mesenteric plexus [125, 126]. Recently a clinical trial provided proof of concept that vagal nerve stimulation could be therapeutically feasible in RA [127]. In this study, 17 patients with RA received vagus nerve stimulation. At day 42, DAS28-CRP levels significantly improved from baseline $(6.05 \pm 0.18$ vs. 4.16$)$ and the results were more robust in biologic naive patients. The proportions of patients achieving ACR20, ACR50 and ACR70 response were 71.4, 57.1 and $28.6 \%$, respectively. Among patients who responded to vagus nerve stimulation, their serum IL-6 levels were significantly reduced from baseline and the reduction in IL- 6 levels correlated with the improvement in disease activity [127].

The sympathetic nervous system, in turn, mediates its effect on the immune system via catecholamine production. Both primary and secondary lymphoid organs are innervated by the sympathetic nervous system [128, 129]. Lymphocytes primarily express the $\beta 2$ adrenergic receptors while cells of the innate immune systems express $\alpha 1$, $\alpha 2$ and $\beta 2$ adrenergic receptors [129]. The effect of sympathetic nervous system on the immune system is more complex. In general, sympathetic activation is able to inhibit the development of a Th1 immune response [128]. Patients with RA have an imbalance of the autonomic nervous system, with increased sympathetic and reduced parasympathetic activities [130]. However, peripheral mononuclear cells from patients with RA express lower levels of $\beta 2$ adrenergic receptors and, therefore, less effective in suppressing $\mathrm{T}$ cell activation and proliferation via $\beta 2$ adrenergic activation [131]. In contrary, catecholamines mediate their effects through $\alpha 1$ adrenergic receptors on the peripheral mononuclear cells [132], leading to increased production of IL-6 [133]. In addition, $\alpha 2$ stimulation promotes the proliferation of fibroblast-like synoviocytes in patients with RA and subsequent production of proinflammatory cytokines [134]. At present, modulations of the sympathetic nervous system yield inconsistent effects in animal arthritis models, and none of them has been evaluated in clinical development programme.

\section{Long-term remission strategies and immune homeostasis}

\section{Dendritic cell therapeutics}

Dendritic cells (DCs) play a key role in both the innate and adaptive immunity. In the periphery, DCs exist as immature cells and undergo differentiation after exposure to proinflammatory cytokines, immune complexes or pathogens and endogenous inflammatory factors that are recognized by 
the Toll-like receptors. Mature DCs then migrate to lymph nodes and present antigens on the MHC molecules to the naive $\mathrm{T}$ cells. Cytokines produced by the DCs also promote the differentiation and maturation of T and B cells [135]. DCs are important for maintaining intra-thymic and peripheral tolerance. Immature DCs recognize and phagocytose apoptotic cells [136], rendering DCs tolerogenic as they produce immunosuppressive cytokines and promote cross tolerance of the $\mathrm{T}$ cells by inducing $\mathrm{T}$ cell anergy, clonal deletion or Treg and suppressor T cell differentiation [137-139]. In normal circumstances, this process does not result in DC maturation. However, failed clearance of apoptotic cells or exposure to maturation signals may induce the production of immunogenic DCs $[140,141]$.

In patients with RA, the synovial DCs are activated in response to pro-inflammatory cytokines, with up-regulation of MHC and co-stimulatory molecule expression [142, 143]. They also produce IL-12 and IL-23 to potentially promote the differentiation of Th1 and Th17 cell [144]. Treatment with TNFi not only ameliorates the clinical symptoms of RA but also reduces the number of activated DCs and inhibits DC maturation $[145,146]$. These observations support the strategy of targeting dendritic cells for the treatment of RA.

In CIA models, administration of low doses of semi-mature DCs inhibits disease progression by enhancing Treg populations and suppresses antigen-specific Th1- and Th17mediated immunity [147]. Treatment of CIA mice with tolerogenic DCs modified by tacrolimus significantly inhibited the severity and progression of disease with the alteration of the proportion of the Th1 and Th17 in the spleen [148]. Similar results have been confirmed by administration of tolerogenic DCs generated by GM-CSF and IL-4 stimulations [149]. These data provide a better understanding and consolidate the role of tolerogenic DCs in the treatment of RA $[150,151]$.

The first clinical study using tolerogenic DCs was carried out in the University of Queensland. In this phase 1 study, tolerogenic DCs were generated by treatment of monocytederived DCs with an inhibitor of NFkB signalling. These tolerogenic DCs are deficient for CD40 expression but express high levels of CD86 [152]. After priming with citrullinated peptide antigens, the tolerogenic DCs were injected intradermally to 18 patients with RA positive for HLA-DR expression. The treatment was well tolerated with no major adverse effects. The results of another phase 1 trial were published recently. It is a randomized, unblinded, placebo-controlled, dose-escalation phase I study. The tolerogenic DCs were generated by pharmacological modulation of monocyte-derived DCs from patients with dexamethasone and vitamin $\mathrm{D}_{3}$, together with a Toll-like receptor-4 agonist. The tolerogenic DCs express high levels of MHC class II molecules and intermediate levels of co-stimulatory molecules CD80 and CD86 and produce high levels of IL-10 and
TGF- $\beta$ [150]. Instead of intradermal injection, 13 patients received three different doses of tolerogenic DCs through intra-articular injection under arthroscopic guidance. The primary objective was to assess the safety of intra-articular injection of tolerogenic DCs in patients with RA. No patient developed an exacerbation of arthritis in the target knee within 5 days of treatment. At day 14, arthroscopic synovitis was present in all participants except for one who received $10 \times 10^{6}$ tolerogenic DCs. Two patients receiving $3 \times 10^{6}$ tolerogenic DCs and one patient receiving $10 \times 10^{6}$ tolerogenic DCs demonstrated improvement in vascularity on day 14 , whereas no improvement was seen in six patients receiving $1 \times 10^{6}$ tolerogenic DCs or placebo. Synovitis improved in one of three patients in each of the $1 \times 10^{6}$ and $3 \times 10^{6}$ tolerogenic DC cohorts and in both assessable patients in the $10 \times 10^{6}$ tolerogenic DC cohorts. There were no trends in DAS2 8 or HAQ score or consistent immunomodulatory effects in peripheral blood [153].

Although tolerogenic DC therapy demonstrates promising results in patients with RA, there are some important issues to be tackled for further clinical evaluation. Administration of tolerogenic DC therapy in patients with established autoimmunity may be less efficacious, and therefore, it should perhaps ideally be given to the patient with RA as early as possible. However, the timing of the treatment is still controversial as potentially elevation of regulatory pathways may suffice. Secondly, the selection of auto-antigens for the generation of tolerogenic DCs may be critical for the efficacy of tolerogenic DC therapy in patients with RA. However, these auto-antigens are not always detected and little is known about the immunodominant profile of these auto-antigens in association with RA pathogenesis and disease progression. Besides, careful consideration should be given to the dose of tolerogenic DCs administered because a high dose of tolerogenic DCs may be potentially immunogenic [154-156]. At present, there is no reliable biomarker of tolerance induction that can be measured after administration of tolerogenic DC therapy. Therefore, further studies are necessary for the development of this immunotherapy.

\section{Conclusion}

Recent advances in the understanding of the pathophysiology of RA facilitate the development of new therapeutic agents. Inhibition of the JAK pathway has already been used in clinical practice, and more selective JAK inhibitors are expected to be available in the near future. The therapeutic potential of BTK inhibitors is being evaluated in phase II studies. As a result, it is expected that over time we will see a balance of therapeutic interventions between biologic and small molecule targeted synthetic DMARDs. 


\section{Compliance with ethical standards}

Conflict of interest There is no conflict of interest for TC. IBM has received honoraria or research funding from AbbVie, BMS, Janssen, Novartis, Pfizer, Roche and UCB.

Open Access This article is distributed under the terms of the Creative Commons Attribution 4.0 International License (http:// creativecommons.org/licenses/by/4.0/), which permits unrestricted use, distribution, and reproduction in any medium, provided you give appropriate credit to the original author(s) and the source, provide a link to the Creative Commons license, and indicate if changes were made.

\section{References}

1. Solomon DH, Karlson EW, Rimm EB, Cannuscio CC, Mandl LA, Manson JE, Stampfer MJ, Curhan GC (2003) Cardiovascular morbidity and mortality in women diagnosed with rheumatoid arthritis. Circulation 107(9):1303-1307

2. Semb AG, Kvien TK, Aastveit AH, Jungner I, Pedersen TR, Walldius G, Holme I (2010) Lipids, myocardial infarction and ischaemic stroke in patients with rheumatoid arthritis in the Apolipoprotein-related Mortality RISk (AMORIS) study. Ann Rheum Dis 69(11):1996-2001

3. Peters MJ, Symmons DP, McCarey D, Dijkmans BA, Nicola P, Kvien TK, McInnes IB, Haentzschel H, Gonzalez-Gay MA, Provan S, Semb A, Sidiropoulos P, Kitas G, Smulders YM, Soubrier M, Szekanecz Z, Sattar N, Nurmohamed MT (2010) EULAR evidence-based recommendations for cardiovascular risk management in patients with rheumatoid arthritis and other forms of inflammatory arthritis. Ann Rheum Dis 69(2):325-331

4. Meune C, Touze E, Trinquart L, Allanore Y (2009) Trends in cardiovascular mortality in patients with rheumatoid arthritis over 50 years: a systematic review and meta-analysis of cohort studies. Rheumatology (Oxford) 48(10):1309-1313

5. Avina-Zubieta JA, Choi HK, Sadatsafavi M, Etminan M, Esdaile JM, Lacaille D (2008) Risk of cardiovascular mortality in patients with rheumatoid arthritis: a meta-analysis of observational studies. Arthritis Rheum 59(12):1690-1697

6. Askling J, Fored CM, Brandt L, Baecklund E, Bertilsson L, Feltelius N, Coster L, Geborek P, Jacobsson LT, Lindblad S, Lysholm J, Rantapaa-Dahlqvist S, Saxne T, Klareskog L (2005) Risks of solid cancers in patients with rheumatoid arthritis and after treatment with tumour necrosis factor antagonists. Ann Rheum Dis 64(10):1421-1426

7. Geborek P, Bladstrom A, Turesson C, Gulfe A, Petersson IF, Saxne T, Olsson H, Jacobsson LT (2005) Tumour necrosis factor blockers do not increase overall tumour risk in patients with rheumatoid arthritis, but may be associated with an increased risk of lymphomas. Ann Rheum Dis 64(5):699-703

8. Thomas E, Brewster DH, Black RJ, Macfarlane GJ (2000) Risk of malignancy among patients with rheumatic conditions. Int $\mathrm{J}$ Cancer 88(3):497-502

9. Smolen JS, Breedveld FC, Burmester GR, Bykerk V, Dougados M, Emery P, Kvien TK, Navarro-Compan MV, Oliver S, Schoels M, Scholte-Voshaar M, Stamm T, Stoffer M, Takeuchi T, Aletaha $\mathrm{D}$, Andreu JL, Aringer M, Bergman M, Betteridge N, Bijlsma H, Burkhardt H, Cardiel M, Combe B, Durez P, Fonseca JE, Gibofsky A, Gomez-Reino JJ, Graninger W, Hannonen P, Haraoui B, Kouloumas M, Landewe R, Martin-Mola E, Nash P, Ostergaard M, Ostor A, Richards P, Sokka-Isler T, Thorne C, Tzioufas AG, van Vollenhoven R, de Wit M, van der Heijde D (2016) Treating rheumatoid arthritis to target: 2014 update of the recommendations of an international task force. Ann Rheum Dis 75(1):3-15

10. van Eijk IC, Nielen MM, van der Horst-Bruinsma I, Tijhuis GJ, Boers M, Dijkmans BA, van Schaardenburg D (2012) Aggressive therapy in patients with early arthritis results in similar outcome compared with conventional care: the STREAM randomized trial. Rheumatology (Oxford) 51(4):686-694

11. Schipper LG, Vermeer M, Kuper HH, Hoekstra MO, Haagsma CJ, Den Broeder AA, van Riel P, Fransen J, van de Laar MA (2012) A tight control treatment strategy aiming for remission in early rheumatoid arthritis is more effective than usual care treatment in daily clinical practice: a study of two cohorts in the Dutch Rheumatoid Arthritis Monitoring registry. Ann Rheum Dis 71(6):845-850

12. Goekoop-Ruiterman YP, de Vries-Bouwstra JK, Kerstens PJ, Nielen MM, Vos K, van Schaardenburg D, Speyer I, Seys PE, Breedveld FC, Allaart CF, Dijkmans BA (2010) DAS-driven therapy versus routine care in patients with recent-onset active rheumatoid arthritis. Ann Rheum Dis 69(1):65-69

13. Soubrier M, Lukas C, Sibilia J, Fautrel B, Roux F, Gossec L, Patternotte S, Dougados M (2011) Disease activity score-driven therapy versus routine care in patients with recent-onset active rheumatoid arthritis: data from the GUEPARD trial and ESPOIR cohort. Ann Rheum Dis 70(4):611-615

14. Gullick NJ, Oakley SP, Zain A, Gibson T, Jones T, Mistlin A, Rees JD, Panayi GS, Kirkham BW (2012) Goal-directed therapy for $\mathrm{RA}$ in routine practice is associated with improved function in patients with disease duration up to 15 years. Rheumatology (Oxford) 51(4):759-761

15. Brenol CV, da Chakr RM, Andrade NP, Toni M, Laurindo IM, Brenol JC, Xavier RM (2015) Daily practice feasibility and effectiveness of treating long-standing rheumatoid arthritis to target with synthetic disease-modifying antirheumatic drugs: a prospective cohort study. Clin Rheumatol 34(10):1781-1785

16. Thiele K, Huscher D, Bischoff S, Spathling-Mestekemper S, Backhaus M, Aringer M, Kohlmann T, Zink A, German Collaborative Arthritis (2013) Performance of the 2011 ACR/ EULAR preliminary remission criteria compared with DAS28 remission in unselected patients with rheumatoid arthritis. Ann Rheum Dis 72(7):1194-1199

17. Provan SA, Semb AG, Hisdal J, Stranden E, Agewall S, Dagfinrud H, Angel K, Atar D, Kvien TK (2011) Remission is the goal for cardiovascular risk management in patients with rheumatoid arthritis: a cross-sectional comparative study. Ann Rheum Dis 70(5):812-817

18. Pavelka K, Chon Y, Newmark R, Lin SL, Baumgartner S, Erondu N (2015) A study to evaluate the safety, tolerability, and efficacy of brodalumab in subjects with rheumatoid arthritis and an inadequate response to methotrexate. J Rheumatol 42(6):912-919

19. Genovese MC, Braun DK, Erickson JS, Berclaz PY, Banerjee S, Heffernan MP, Carlier H (2016) Safety and efficacy of open-label subcutaneous ixekizumab treatment for 48 weeks in a phase II study in biologic-naive and TNF-IR patients with rheumatoid arthritis. J Rheumatol 43(2):289-297

20. Genovese MC, Greenwald M, Cho CS, Berman A, Jin L, Cameron GS, Benichou O, Xie L, Braun D, Berclaz PY, Banerjee S (2014) A phase II randomized study of subcutaneous ixekizumab, an anti-interleukin-17 monoclonal antibody, in rheumatoid arthritis patients who were naive to biologic agents or had an inadequate response to tumor necrosis factor inhibitors. Arthritis \& Rheumatology 66(7):1693-1704

21. Blanco FJ, Moricke R, Dokoupilova E, Codding C, Neal J, Andersson M, Rohrer S, Richards H. (2017) Secukinumab in active rheumatoid arthritis: a randomized, double-blind placebo and active comparator controlled phase 3 study. Arthritis Rheumatol. doi:0.1002/art.40070 
22. Genovese MC, Durez P, Richards HB, Supronik J, Dokoupilova E, Aelion JA, Lee SH, Codding CE, Kellner H, Ikawa T, Hugot S, Ligozio G, Mpofu S (2014) One-year efficacy and safety results of secukinumab in patients with rheumatoid arthritis: phase II, dosefinding, double-blind, randomized, placebo-controlled study. J Rheumatol 41(3):414-421

23. Genovese MC, Durez P, Richards HB, Supronik J, Dokoupilova E, Mazurov V, Aelion JA, Lee SH, Codding CE, Kellner H, Ikawa T, Hugot S, Mpofu S (2013) Efficacy and safety of secukinumab in patients with rheumatoid arthritis: a phase II, dose-finding, double-blind, randomised, placebo controlled study. Ann Rheum Dis 72(6):863-869

24. Senolt L, Leszczynski P, Dokoupilova E, Gothberg M, Valencia X, Hansen BB, Canete JD (2015) Efficacy and safety of antiinterleukin-20 monoclonal antibody in patients with rheumatoid arthritis: a randomized phase IIa trial. Arthritis \& Rheumatology 67(6): $1438-1448$

25. Bussolino F, Wang JM, Defilippi P, Turrini F, Sanavio F, Edgell CJ, Aglietta M, Arese P, Mantovani A (1989) Granulocyte- and granulocyte-macrophage-colony stimulating factors induce human endothelial cells to migrate and proliferate. Nature 337(6206):471-473

26. Leizer T, Cebon J, Layton JE, Hamilton JA (1990) Cytokine regulation of colony-stimulating factor production in cultured human synovial fibroblasts: I. Induction of GM-CSF and G-CSF production by interleukin-1 and tumor necrosis factor. Blood 76(10): 1989-1996

27. Campbell IK, Novak U, Cebon J, Layton JE, Hamilton JA (1991) Human articular cartilage and chondrocytes produce hemopoietic colony-stimulating factors in culture in response to IL-1. J Immunol 147(4):1238-1246

28. Hamilton JA (2008) Colony-stimulating factors in inflammation and autoimmunity. Nat Rev Immunol 8(7):533-544

29. Hansen G, Hercus TR, McClure BJ, Stomski FC, Dottore M, Powell J, Ramshaw H, Woodcock JM, Xu Y, Guthridge M, McKinstry WJ, Lopez AF, Parker MW (2008) The structure of the GM-CSF receptor complex reveals a distinct mode of cytokine receptor activation. Cell 134(3):496-507

30. Jenkins BJ, Blake TJ, Gonda TJ (1998) Saturation mutagenesis of the beta subunit of the human granulocyte-macrophage colonystimulating factor receptor shows clustering of constitutive mutations, activation of ERK MAP kinase and STAT pathways, and differential beta subunit tyrosine phosphorylation. Blood 92(6): 1989-2002

31. Sato N, Sakamaki K, Terada N, Arai K, Miyajima A (1993) Signal transduction by the high-affinity GM-CSF receptor: two distinct cytoplasmic regions of the common beta subunit responsible for different signaling. EMBO J 12(11):4181-4189

32. Fleetwood AJ, Cook AD, Hamilton JA (2005) Functions of granulocyte-macrophage colony-stimulating factor. Crit Rev Immunol 25(5):405-428

33. Fleetwood AJ, Lawrence T, Hamilton JA, Cook AD (2007) Granulocyte-macrophage colony-stimulating factor (CSF) and macrophage CSF-dependent macrophage phenotypes display differences in cytokine profiles and transcription factor activities: implications for CSF blockade in inflammation. J Immunol 178(8):5245-5252

34. Xu Y, Zhan Y, Lew AM, Naik SH, Kershaw MH (2007) Differential development of murine dendritic cells by GM-CSF versus Flt3 ligand has implications for inflammation and trafficking. J Immunol 179(11):7577-7584

35. Gilliet M, Boonstra A, Paturel C, Antonenko S, Xu XL, Trinchieri G, O'Garra A, Liu YJ (2002) The development of murine plasmacytoid dendritic cell precursors is differentially regulated by FLT3-ligand and granulocyte/macrophage colony-stimulating factor. J Exp Med 195(7):953-958
36. Li BZ, Ye QL, Xu WD, Li JH, Ye DQ, Xu Y (2013) GM-CSF alters dendritic cells in autoimmune diseases. Autoimmunity 46(7):409-418

37. Conti L, Gessani S (2008) GM-CSF in the generation of dendritic cells from human blood monocyte precursors: recent advances. Immunobiology 213(9-10):859-870

38. Lebre MC, Tak PP (2008) Dendritic cell subsets: their roles in rheumatoid arthritis. Acta reumatologica portuguesa 33(1):35-45

39. Bell AL, Magill MK, McKane WR, Kirk F, Irvine AE (1995) Measurement of colony-stimulating factors in synovial fluid: potential clinical value. Rheumatol Int 14(5):177-182

40. Field M, Clinton L (1993) Expression of GM-CSF receptor in rheumatoid arthritis. Lancet 342(8881): 1244

41. Berenbaum F, Rajzbaum G, Amor B, Toubert A (1994) Evidence for GM-CSF receptor expression in synovial tissue. An analysis by semi-quantitative polymerase chain reaction on rheumatoid arthritis and osteoarthritis synovial biopsies. Eur Cytokine Netw 5(1):43-46

42. Jang J, Lim DS, Choi YE, Jeong Y, Yoo SA, Kim WU, Bae YS (2006) MLN51 and GM-CSF involvement in the proliferation of fibroblast-like synoviocytes in the pathogenesis of rheumatoid arthritis. Arthritis Research \& Therapy 8(6):R170

43. Torchinsky MB, Garaude J, Martin AP, Blander JM (2009) Innate immune recognition of infected apoptotic cells directs $\mathrm{T}(\mathrm{H}) 17$ cell differentiation. Nature 458(7234):78-82

44. MacDonald KP, Pettit AR, Quinn C, Thomas GJ, Thomas R (1999) Resistance of rheumatoid synovial dendritic cells to the immunosuppressive effects of IL-10. J Immunol 163(10):5599 5607

45. Radstake TR, van Lent PL, Pesman GJ, Blom AB, Sweep FG, Ronnelid J, Adema GJ, Barrera P, van den Berg WB (2004) High production of proinflammatory and Th1 cytokines by dendritic cells from patients with rheumatoid arthritis, and down regulation upon FcgammaR triggering. Ann Rheum Dis 63(6):696-702

46. Tsark EC, Wang W, Teng YC, Arkfeld D, Dodge GR, Kovats S (2002) Differential MHC class II-mediated presentation of rheumatoid arthritis autoantigens by human dendritic cells and macrophages. J Immunol 169(11):6625-6633

47. Cook AD, Braine EL, Campbell IK, Rich MJ, Hamilton JA (2001) Blockade of collagen-induced arthritis post-onset by antibody to granulocyte-macrophage colony-stimulating factor (GM-CSF): requirement for GM-CSF in the effector phase of disease. Arthritis Res 3(5):293-298

48. Cornish AL, Campbell IK, McKenzie BS, Chatfield S, Wicks IP (2009) G-CSF and GM-CSF as therapeutic targets in rheumatoid arthritis. Nat Rev Rheumatol 5(10):554-559

49. Avci AB, Feist E, Burmester GR (2016) Targeting GM-CSF in rheumatoid arthritis. Clin Exp Rheumatol 34(4 Suppl 98):39-44

50. Burmester GR, Weinblatt ME, McInnes IB, Porter D, Barbarash O, Vatutin M, Szombati I, Esfandiari E, Sleeman MA, Kane CD, Cavet G, Wang B, Godwood A, Magrini F, E.S. Group (2013) Efficacy and safety of mavrilimumab in subjects with rheumatoid arthritis. Ann Rheum Dis 72(9):1445-1452

51. Heinrich PC, Behrmann I, Muller-Newen G, Schaper F, Graeve L (1998) Interleukin-6-type cytokine signalling through the gp130/ Jak/STAT pathway. Biochem J 334(Pt 2):297-314

52. Imada K, Leonard WJ (2000) The Jak-STAT pathway. Mol Immunol 37(1-2):1-11

53. Schindler C, Levy DE, Decker T (2007) JAK-STAT signaling: from interferons to cytokines. J Biol Chem 282(28):20059-20063

54. Rawlings JS, Rosler KM, Harrison DA (2004) The JAK/STAT signaling pathway. J Cell Sci 117(Pt 8):1281-1283

55. Yamaoka K, Saharinen P, Pesu M, Holt VE 3rd, Silvennoinen O, O'Shea JJ (2004) The Janus kinases (Jaks). Genome Biol 5(12): 253 
56. Shuai K, Liu B (2003) Regulation of JAK-STAT signalling in the immune system. Nat Rev Immunol 3(11):900-911

57. Pesu M, Candotti F, Husa M, Hofmann SR, Notarangelo LD, O'Shea JJ (2005) Jak3, severe combined immunodeficiency, and a new class of immunosuppressive drugs. Immunol Rev 203:127142

58. Feist E, Burmester GR (2013) Small molecules targeting JAKs - a new approach in the treatment of rheumatoid arthritis. Rheumatology (Oxford) 52(8):1352-1357

59. Lee EB, Fleischmann R, Hall S, Wilkinson B, Bradley JD, Gruben D, Koncz T, Krishnaswami S, Wallenstein GV, Zang C, Zwillich SH, van Vollenhoven RF, Investigators OS (2014) Tofacitinib versus methotrexate in rheumatoid arthritis. N Engl J Med 370(25): $2377-2386$

60. van der Heijde D, Tanaka Y, Fleischmann R, Keystone E, Kremer J, Zerbini C, Cardiel MH, Cohen S, Nash P, Song YW, Tegzova D, Wyman BT, Gruben D, Benda B, Wallenstein G, Krishnaswami S, Zwillich SH, Bradley JD, Connell CA, Investigators OS (2013) Tofacitinib (CP-690,550) in patients with rheumatoid arthritis receiving methotrexate: twelve-month data from a twenty-fourmonth phase III randomized radiographic study. Arthritis Rheum 65(3):559-570

61. Burmester GR, Blanco R, Charles-Schoeman C, Wollenhaupt J, Zerbini C, Benda B, Gruben D, Wallenstein G, Krishnaswami S, Zwillich SH, Koncz T, Soma K, Bradley J, Mebus C, O.S. investigators (2013) Tofacitinib (CP-690,550) in combination with methotrexate in patients with active rheumatoid arthritis with an inadequate response to tumour necrosis factor inhibitors: a randomised phase 3 trial. Lancet 381(9865):451-460

62. van Vollenhoven RF, Fleischmann R, Cohen S, Lee EB, Garcia Meijide JA, Wagner S, Forejtova S, Zwillich SH, Gruben D, Koncz T, Wallenstein GV, Krishnaswami S, Bradley JD, Wilkinson B, Investigators OS (2012) Tofacitinib or adalimumab versus placebo in rheumatoid arthritis. N Engl J Med 367(6):508519

63. Fleischmann R, Kremer J, Cush J, Schulze-Koops H, Connell CA, Bradley JD, Gruben D, Wallenstein GV, Zwillich SH, Kanik KS, Investigators OS (2012) Placebo-controlled trial of tofacitinib monotherapy in rheumatoid arthritis. N Engl J Med 367(6):495507

64. Kremer J, Li ZG, Hall S, Fleischmann R, Genovese M, MartinMola E, Isaacs JD, Gruben D, Wallenstein G, Krishnaswami S, Zwillich SH, Koncz T, Riese R, Bradley J (2013) Tofacitinib in combination with nonbiologic disease-modifying antirheumatic drugs in patients with active rheumatoid arthritis: a randomized trial. Ann Intern Med 159(4):253-261

65. Winthrop KL, Yamanaka H, Valdez H, Mortensen E, Chew R, Krishnaswami S, Kawabata T, Riese R (2014) Herpes zoster and tofacitinib therapy in patients with rheumatoid arthritis. Arthritis \& Rheumatology 66(10):2675-2684

66. Dougados M, van der Heijde D, Chen YC, Greenwald M, Drescher E, Liu J, Beattie S, Witt S, de la Torre I, Gaich C, Rooney T, Schlichting D, de Bono S, Emery P (2017) Baricitinib in patients with inadequate response or intolerance to conventional synthetic DMARDs: results from the RA-BUILD study. Ann Rheum Dis 76(1):88-95

67. Genovese MC, Kremer J, Zamani O, Ludivico C, Krogulec M, Xie L, Beattie SD, Koch AE, Cardillo TE, Rooney TP, Macias WL, de Bono S, Schlichting DE, Smolen JS (2016) Baricitinib in patients with refractory rheumatoid arthritis. N Engl J Med 374(13):1243-1252

68. Fleischmann R, Schiff M, van der Heijde D, Ramos-Remus C, Spindler A, Stanislav M, Zerbini CA, Gurbuz S, Dickson C, de Bono S, Schlichting D, Beattie S, Kuo WL, Rooney T, Macias W, Takeuchi T (2016) Baricitinib, methotrexate, or combination in patients with rheumatoid arthritis and no or limited prior disease- modifying antirheumatic drug treatment. Arthritis Rheumatol 69(3):506-517

69. Taylor PC, Keystone EC, van der Heijde D, Weinblatt ME, Del Carmen Morales L, Reyes Gonzaga J, Yakushin S, Ishii T, Emoto K, Beattie S, Arora V, Gaich C, Rooney T, Schlichting D, Macias WL, de Bono S, Tanaka Y (2017) Baricitinib versus placebo or adalimumab in rheumatoid arthritis. N Engl J Med 376(7):652-662

70. Westhovens R, Taylor PC, Alten R, Pavlova D, Enriquez-Sosa F, Mazur M, Greenwald M, Van der Aa A, Vanhoutte F, Tasset C, Harrison P (2016) Filgotinib (GLPG0634/GS-6034), an oral JAK1 selective inhibitor, is effective in combination with methotrexate (MTX) in patients with active rheumatoid arthritis and insufficient response to MTX: results from a randomised, dosefinding study (DARWIN 1). Ann Rheum Dis. doi:10.1136/ annrheumdis-2016-210104

71. Kavanaugh A, Kremer J, Ponce L, Cseuz R, Reshetko OV, Stanislavchuk M, Greenwald M, Van der Aa A,Vanhoutte F, Tasset C,Harrison P (2016) Filgotinib (GLPG0634/GS-6034), an oral selective JAK1 inhibitor, is effective as monotherapy in patients with active rheumatoid arthritis: results from a randomised, dose-finding study (DARWIN 2). Ann Rheum Dis. 10.1136/ annrheumdis-2016-210105

72. Genovese MC, Smolen JS, Weinblatt ME, Burmester GR, Meerwein S, Camp HS, Wang L, Othman AA, Khan N, Pangan AL, Jungerwirth S (2016) Efficacy and safety of ABT-494, a selective JAK-1 inhibitor, in a phase IIb study in patients with rheumatoid arthritis and an inadequate response to methotrexate. Arthritis \& rheumatology 68(12):2857-2866

73. Kremer JM, Emery P, Camp HS, Friedman A, Wang L, Othman AA, Khan N, Pangan AL, Jungerwirth S, Keystone EC (2016) A phase IIb study of ABT-494, a selective JAK-1 inhibitor, in patients with rheumatoid arthritis and an inadequate response to antitumor necrosis factor therapy. Arthritis \& rheumatology 68(12): $2867-2877$

74. Satterthwaite AB, Li Z, Witte ON (1998) Btk function in B cell development and response. Semin Immunol 10(4):309-316

75. Maas A, Hendriks RW (2001) Role of Bruton's tyrosine kinase in B cell development. Dev Immunol 8(3-4):171-181

76. Mohamed AJ, Yu L, Backesjo CM, Vargas L, Faryal R, Aints A, Christensson B, Berglof A, Vihinen M, Nore BF, Smith CI (2009) Bruton's tyrosine kinase (Btk): function, regulation, and transformation with special emphasis on the PH domain. Immunol Rev 228(1):58-73

77. Khan WN (2001) Regulation of B lymphocyte development and activation by Bruton's tyrosine kinase. Immunol Res 23(2-3):147-156

78. Tsukada S, Saffran DC, Rawlings DJ, Parolini O, Allen RC, Klisak I, Sparkes RS, Kubagawa H, Mohandas T, Quan S et al (1993) Deficient expression of a B cell cytoplasmic tyrosine kinase in human X-linked agammaglobulinemia. Cell 72(2):279-290

79. Rawlings DJ, Saffran DC, Tsukada S, Largaespada DA, Grimaldi JC, Cohen L, Mohr RN, Bazan JF, Howard M, Copeland NG et al (1993) Mutation of unique region of Bruton's tyrosine kinase in immunodeficient XID mice. Science 261(5119):358-361

80. Mukhopadhyay S, Mohanty M, Mangla A, George A, Bal V, Rath S, Ravindran B (2002) Macrophage effector functions controlled by Bruton's tyrosine kinase are more crucial than the cytokine balance of $\mathrm{T}$ cell responses for microfilarial clearance. $\mathrm{J}$ Immunol 168(6):2914-2921

81. Mukhopadhyay S, George A, Bal V, Ravindran B, Rath S (1999) Bruton's tyrosine kinase deficiency in macrophages inhibits nitric oxide generation leading to enhancement of IL-12 induction. J Immunol 163(4):1786-1792

82. Jansson L, Holmdahl R (1993) Genes on the X chromosome affect development of collagen-induced arthritis in mice. Clin Exp Immunol 94(3):459-465 
83. Kleinau S, Martinsson P, Heyman B (2000) Induction and suppression of collagen-induced arthritis is dependent on distinct fcgamma receptors. J Exp Med 191(9):1611-1616

84. Evans EK, Tester R, Aslanian S, Karp R, Sheets M, Labenski MT, Witowski SR, Lounsbury H, Chaturvedi P, Mazdiyasni H, Zhu Z, Nacht M, Freed MI, Petter RC, Dubrovskiy A, Singh J, Westlin WF (2013) Inhibition of Btk with CC-292 provides early pharmacodynamic assessment of activity in mice and humans. J Pharmacol Exp Ther 346(2):219-228

85. Pan Z, Scheerens H, Li SJ, Schultz BE, Sprengeler PA, Burrill LC, Mendonca RV, Sweeney MD, Scott KC, Grothaus PG, Jeffery DA, Spoerke JM, Honigberg LA, Young PR, Dalrymple SA, Palmer JT (2007) Discovery of selective irreversible inhibitors for Bruton's tyrosine kinase. ChemMedChem 2(1):58-61

86. Norman P (2016) Investigational Bruton's tyrosine kinase inhibitors for the treatment of rheumatoid arthritis. Expert Opin Investig Drugs 25(8):891-899

87. Cantley LC (2002) The phosphoinositide 3-kinase pathway. Science 296(5573):1655-1657

88. Foster FM, Traer CJ, Abraham SM, Fry MJ (2003) The phosphoinositide (PI) 3-kinase family. J Cell Sci 116(Pt 15): 3037-3040

89. Okkenhaug K, Vanhaesebroeck B (2003) PI3K in lymphocyte development, differentiation and activation. Nat Rev Immunol 3(4):317-330

90. Okkenhaug K, Bilancio A, Farjot G, Priddle H, Sancho S, Peskett E, Pearce W, Meek SE, Salpekar A, Waterfield MD, Smith AJ, Vanhaesebroeck B (2002) Impaired B and T cell antigen receptor signaling in p110delta PI 3-kinase mutant mice. Science 297(5583):1031-1034

91. Okkenhaug K, Patton DT, Bilancio A, Garcon F, Rowan WC, Vanhaesebroeck B (2006) The p110delta isoform of phosphoinositide 3-kinase controls clonal expansion and differentiation of Th cells. J Immunol 177(8):5122-5128

92. Nashed BF, Zhang T, Al-Alwan M, Srinivasan G, Halayko AJ, Okkenhaug K, Vanhaesebroeck B, Hayglass KT, Marshall AJ (2007) Role of the phosphoinositide 3-kinase p110delta in generation of type 2 cytokine responses and allergic airway inflammation. Eur J Immunol 37(2):416-424

93. Patton DT, Garden OA, Pearce WP, Clough LE, Monk CR, Leung E, Rowan WC, Sancho S, Walker LS, Vanhaesebroeck B, Okkenhaug K (2006) Cutting edge: the phosphoinositide 3kinase p110 delta is critical for the function of CD4+CD25+ Foxp3+ regulatory T cells. J Immunol 177(10):6598-6602

94. Bilancio A, Okkenhaug K, Camps M, Emery JL, Ruckle T, Rommel C, Vanhaesebroeck B (2006) Key role of the p110delta isoform of PI3K in B-cell antigen and IL-4 receptor signaling: comparative analysis of genetic and pharmacologic interference with p110delta function in B cells. Blood 107(2):642-650

95. Jou ST, Carpino N, Takahashi Y, Piekorz R, Chao JR, Carpino N, Wang D, Ihle JN (2002) Essential, nonredundant role for the phosphoinositide 3-kinase p110delta in signaling by the B-cell receptor complex. Mol Cell Biol 22(24):8580-8591

96. Ramadani F, Bolland DJ, Garcon F, Emery JL, Vanhaesebroeck B, Corcoran AE, Okkenhaug K (2010) The PI3K isoforms p110alpha and p110delta are essential for pre-B cell receptor signaling and $\mathrm{B}$ cell development. Sci Signal 3(134):ra60

97. Clayton E, Bardi G, Bell SE, Chantry D, Downes CP, Gray A, Humphries LA, Rawlings D, Reynolds H, Vigorito E, Turner M (2002) A crucial role for the p110delta subunit of phosphatidylinositol 3-kinase in B cell development and activation. J Exp Med 196(6):753-763

98. Thomas MS, Mitchell JS, DeNucci CC, Martin AL, Shimizu Y (2008) The p110gamma isoform of phosphatidylinositol 3-kinase regulates migration of effector CD4 $\mathrm{T}$ lymphocytes into peripheral inflammatory sites. J Leukoc Biol 84(3):814-823

99. Reif K, Okkenhaug K, Sasaki T, Penninger JM, Vanhaesebroeck B, Cyster JG (2004) Cutting edge: differential roles for phosphoinositide 3-kinases, p110gamma and p110delta, in lymphocyte chemotaxis and homing. J Immunol 173(4):2236-2240

100. Li Z, Jiang H, Xie W, Zhang Z, Smrcka AV, Wu D (2000) Roles of PLC-beta2 and -beta3 and PI3Kgamma in chemoattractantmediated signal transduction. Science 287(5455):1046-1049

101. Hirsch E, Katanaev VL, Garlanda C, Azzolino O, Pirola L, Silengo L, Sozzani S, Mantovani A, Altruda F, Wymann MP (2000) Central role for G protein-coupled phosphoinositide 3kinase gamma in inflammation. Science 287(5455):1049-1053

102. Condliffe AM, Davidson K, Anderson KE, Ellson CD, Crabbe T, Okkenhaug K, Vanhaesebroeck B, Turner M, Webb L, Wymann MP, Hirsch E, Ruckle T, Camps M, Rommel C, Jackson SP, Chilvers ER, Stephens LR, Hawkins PT (2005) Sequential activation of class IB and class IA PI3K is important for the primed respiratory burst of human but not murine neutrophils. Blood 106(4):1432-1440

103. Del Prete A, Vermi W, Dander E, Otero K, Barberis L, Luini W, Bernasconi S, Sironi M, Santoro A, Garlanda C, Facchetti F, Wymann MP, Vecchi A, Hirsch E, Mantovani A, Sozzani S (2004) Defective dendritic cell migration and activation of adaptive immunity in PI3Kgamma-deficient mice. EMBO J 23(17): 3505-3515

104. Krishnamoorthy N, Oriss TB, Paglia M, Fei M, Yarlagadda M, Vanhaesebroeck B, Ray A, Ray P (2008) Activation of c-Kit in dendritic cells regulates $\mathrm{T}$ helper cell differentiation and allergic asthma. Nat Med 14(5):565-573

105. Rommel C, Camps M, Ji H (2007) PI3K delta and PI3K gamma: partners in crime in inflammation in rheumatoid arthritis and beyond? Nat Rev Immunol 7(3):191-201

106. Banham-Hall E, Clatworthy MR, Okkenhaug K (2012) The therapeutic potential for PI3K inhibitors in autoimmune rheumatic diseases. Open Rheumatol J 6:245-258

107. Camps M, Ruckle T, Ji H, Ardissone V, Rintelen F, Shaw J, Ferrandi C, Chabert C, Gillieron C, Francon B, Martin T, Gretener D, Perrin D, Leroy D, Vitte PA, Hirsch E, Wymann MP, Cirillo R, Schwarz MK, Rommel C (2005) Blockade of PI3Kgamma suppresses joint inflammation and damage in mouse models of rheumatoid arthritis. Nat Med 11(9):936-943

108. Hayer S, Pundt N, Peters MA, Wunrau C, Kuhnel I, Neugebauer K, Strietholt S, Zwerina J, Korb A, Penninger J, Joosten LA, Gay S, Ruckle T, Schett G, Pap T (2009) PI3Kgamma regulates cartilage damage in chronic inflammatory arthritis. FASEB J 23(12): 4288-4298

109. Zou L, Zhang G, Liu L, Chen C, Cao X, Cai J (2016) Relationship between PI3K pathway and angiogenesis in CIA rat synovium. Am J Transl Res 8(7):3141-3147

110. Sujobert P, Rioufol C, Salles GA (2016) Idelalisib: targeting the PI3 kinase pathway in non-Hodgkin lymphoma. Cancer J 22(1): $12-16$

111. Nair KS, Cheson B (2016) The role of idelalisib in the treatment of relapsed and refractory chronic lymphocytic leukemia. Ther Adv Hematol 7(2):69-84

112. Barrientos JC (2016) Idelalisib for the treatment of indolent nonHodgkin lymphoma: a review of its clinical potential. Onco Targets Ther 9:2945-2953

113. Yang Q, Modi P, Newcomb T, Queva C, Gandhi V (2015) Idelalisib: first-in-class PI3K delta inhibitor for the treatment of chronic lymphocytic leukemia, small lymphocytic leukemia, and follicular lymphoma. Clin Cancer Res 21(7):1537-1542 
114. Courtright LJ, Kuzell WC (1965) Sparing effect of neurological deficit and trauma on the course of adjuvant arthritis in the rat. Ann Rheum Dis 24(4):360-368

115. Koopman FA, Stoof SP, Straub RH, Van Maanen MA, Vervoordeldonk MJ, Tak PP (2011) Restoring the balance of the autonomic nervous system as an innovative approach to the treatment of rheumatoid arthritis. Mol Med 17(9-10):937-948

116. Borovikova LV, Ivanova S, Zhang M, Yang H, Botchkina GI, Watkins LR, Wang H, Abumrad N, Eaton JW, Tracey KJ (2000) Vagus nerve stimulation attenuates the systemic inflammatory response to endotoxin. Nature 405(6785):458-462

117. Wang H, Yu M, Ochani M, Amella CA, Tanovic M, Susarla S, Li JH, Wang H, Yang H, Ulloa L, Al-Abed Y, Czura CJ, Tracey KJ (2003) Nicotinic acetylcholine receptor alpha7 subunit is an essential regulator of inflammation. Nature 421(6921):384-388

118. de Jonge WJ, Ulloa L (2007) The alpha7 nicotinic acetylcholine receptor as a pharmacological target for inflammation. Br J Pharmacol 151(7):915-929

119. van Maanen MA, Stoof SP, van der Zanden EP, de Jonge WJ, Janssen RA, Fischer DF, Vandeghinste N, Brys R, Vervoordeldonk MJ, Tak PP (2009) The alpha7 nicotinic acetylcholine receptor on fibroblast-like synoviocytes and in synovial tissue from rheumatoid arthritis patients: a possible role for a key neurotransmitter in synovial inflammation. Arthritis Rheum 60(5): $1272-1281$

120. Westman M, Engstrom M, Catrina AI, Lampa J (2009) Cell specific synovial expression of nicotinic alpha 7 acetylcholine receptor in rheumatoid arthritis and psoriatic arthritis. Scand J Immunol 70(2):136-140

121. van Maanen MA, Lebre MC, van der Poll T, LaRosa GJ, Elbaum D, Vervoordeldonk MJ, Tak PP (2009) Stimulation of nicotinic acetylcholine receptors attenuates collagen-induced arthritis in mice. Arthritis Rheum 60(1):114-122

122. Li T, Zuo X, Zhou Y, Wang Y, Zhuang H, Zhang L, Zhang H, Xiao $X(2010)$ The vagus nerve and nicotinic receptors involve inhibition of HMGB1 release and early pro-inflammatory cytokines function in collagen-induced arthritis. J Clin Immunol 30(2): 213-220

123. van Maanen MA, Stoof SP, Larosa GJ, Vervoordeldonk MJ, Tak PP (2010) Role of the cholinergic nervous system in rheumatoid arthritis: aggravation of arthritis in nicotinic acetylcholine receptor alpha7 subunit gene knockout mice. Ann Rheum Dis 69(9):17171723

124. Waldburger JM, Boyle DL, Pavlov VA, Tracey KJ, Firestein GS (2008) Acetylcholine regulation of synoviocyte cytokine expression by the alpha7 nicotinic receptor. Arthritis Rheum 58(11): 3439-3449

125. Buijs RM, van der Vliet J, Garidou ML, Huitinga I, Escobar C (2008) Spleen vagal denervation inhibits the production of antibodies to circulating antigens. PLoS One 3(9):e3152

126. Rosas-Ballina M, Ochani M, Parrish WR, Ochani K, Harris YT, Huston JM, Chavan S, Tracey KJ (2008) Splenic nerve is required for cholinergic antiinflammatory pathway control of TNF in endotoxemia. Proc Natl Acad Sci U S A 105(31):11008-11013

127. Koopman FA, Chavan SS, Miljko S, Grazio S, Sokolovic S, Schuurman PR, Mehta AD, Levine YA, Faltys M, Zitnik R, Tracey KJ, Tak PP (2016) Vagus nerve stimulation inhibits cytokine production and attenuates disease severity in rheumatoid arthritis. Proc Natl Acad Sci U S A 113(29):8284-8289

128. Elenkov IJ, Wilder RL, Chrousos GP, Vizi ES (2000) The sympathetic nerve - an integrative interface between two supersystems: the brain and the immune system. Pharmacol Rev 52(4):595-638

129. Nance DM, Sanders VM (2007) Autonomic innervation and regulation of the immune system (1987-2007). Brain Behav Immun 21(6):736-745
130. Evrengul H, Dursunoglu D, Cobankara V, Polat B, Seleci D, Kabukcu S, Kaftan A, Semiz E, Kilic M (2004) Heart rate variability in patients with rheumatoid arthritis. Rheumatol Int 24(4): 198-202

131. Baerwald C, Graefe C, Muhl C, Von Wichert P, Krause A (1992) Beta 2-adrenergic receptors on peripheral blood mononuclear cells in patients with rheumatic diseases. Eur J Clin Investig 22(Suppl 1):42-46

132. Straub RH, Harle P (2005) Sympathetic neurotransmitters in joint inflammation. Rheum Dis Clin N Am 31(1):43-59 viii

133. Heijnen CJ, Rouppe van der Voort C, Wulffraat N, van der Net J, Kuis W, Kavelaars A (1996) Functional alpha 1-adrenergic receptors on leukocytes of patients with polyarticular juvenile rheumatoid arthritis. J Neuroimmunol 71(1-2):223-226

134. Bellinger DL, Millar BA, Perez S, Carter J, Wood C, ThyagaRajan S, Molinaro C, Lubahn C, Lorton D (2008) Sympathetic modulation of immunity: relevance to disease. Cell Immunol 252(1-2): $27-56$

135. Steinman RM (2012) Decisions about dendritic cells: past, present, and future. Annu Rev Immunol 30:1-22

136. Somersan S, Bhardwaj N (2001) Tethering and tickling: a new role for the phosphatidylserine receptor. J Cell Biol 155(4):501-504

137. Steinman RM, Nussenzweig MC (2002) Avoiding horror autotoxicus: the importance of dendritic cells in peripheral $\mathrm{T}$ cell tolerance. Proc Natl Acad Sci U S A 99(1):351-358

138. Maldonado RA, von Andrian UH (2010) How tolerogenic dendritic cells induce regulatory T cells. Adv Immunol 108:111-165

139. Roncarolo MG, Gregori S, Battaglia M, Bacchetta R, Fleischhauer $\mathrm{K}$, Levings MK (2006) Interleukin-10-secreting type 1 regulatory $\mathrm{T}$ cells in rodents and humans. Immunol Rev 212:28-50

140. Skoberne M, Beignon AS, Larsson M, Bhardwaj N (2005) Apoptotic cells at the crossroads of tolerance and immunity. Curr Top Microbiol Immunol 289:259-292

141. Skoberne M, Somersan S, Almodovar W, Truong T, Petrova K, Henson PM, Bhardwaj N (2006) The apoptotic-cell receptor CR3, but not alphavbeta5, is a regulator of human dendritic-cell immunostimulatory function. Blood 108(3):947-955

142. Pettit AR, MacDonald KP, O'Sullivan B, Thomas R (2000) Differentiated dendritic cells expressing nuclear RelB are predominantly located in rheumatoid synovial tissue perivascular mononuclear cell aggregates. Arthritis Rheum 43(4):791-800

143. Martin CA, Carsons SE, Kowalewski R, Bernstein D, Valentino M, Santiago-Schwarz F (2003) Aberrant extracellular and dendritic cell (DC) surface expression of heat shock protein (hsp) 70 in the rheumatoid joint: possible mechanisms of hsp/DC-mediated cross-priming. J Immunol 171(11):5736-5742

144. Lebre MC, Jongbloed SL, Tas SW, Smeets TJ, McInnes IB, Tak PP (2008) Rheumatoid arthritis synovium contains two subsets of CD83-DC-LAMP- dendritic cells with distinct cytokine profiles. Am J Pathol 172(4):940-950

145. van Lieshout AW, Barrera P, Smeets RL, Pesman GJ, van Riel PL, van den Berg WB, Radstake TR (2005) Inhibition of TNF alpha during maturation of dendritic cells results in the development of semi-mature cells: a potential mechanism for the beneficial effects of TNF alpha blockade in rheumatoid arthritis. Ann Rheum Dis 64(3):408-414

146. Balanescu A, Radu E, Nat R, Regalia T, Bojinca V, Ionescu R, Balanescu S, Savu C, Predeteanu D (2005) Early and late effect of infliximab on circulating dendritic cells phenotype in rheumatoid arthritis patients. Int J Clin Pharmacol Res 25(1):9-18

147. Park JE, Jang J, Choi JH, Kang MS, Woo YJ, Seong YR, Choi CB, Lee HS, Bae SC, Bae YS (2015) DC-based immunotherapy combined with low-dose methotrexate effective in the treatment of advanced CIA in mice. J Immunol Res 2015:834085

148. Ren Y, Yang Y, Yang J, Xie R, Fan H (2014) Tolerogenic dendritic cells modified by tacrolimus suppress CD4(+) T-cell proliferation 
and inhibit collagen-induced arthritis in mice. Int Immunopharmacol 21(1):247-254

149. Zhang L, Fu J, Sheng K, Li Y, Song S, Li P, Song S, Wang Q, Chen J, Yu J, Wei W (2015) Bone marrow CD11b(+)F4/80(+) dendritic cells ameliorate collagen-induced arthritis through modulating the balance between Treg and Th17. Int Immunopharmacol 25(1):96-105

150. Hilkens CM, Isaacs JD (2013) Tolerogenic dendritic cell therapy for rheumatoid arthritis: where are we now? Clin Exp Immunol 172(2):148-157

151. Ahmed MS, Bae YS (2016) Dendritic cell-based immunotherapy for rheumatoid arthritis: from bench to bedside. Immune Netw 16(1):44-51

152. Martin E, O'Sullivan B, Low P, Thomas R (2003) Antigen-specific suppression of a primed immune response by dendritic cells mediated by regulatory $\mathrm{T}$ cells secreting interleukin-10. Immunity 18(1):155-167
153. Bell GM, Anderson AE, Diboll J, Reece R, Eltherington O, Harry RA, Fouweather T, MacDonald C, Chadwick T, McColl E, Dunn J, Dickinson AM, Hilkens CM, Isaacs JD (2017) Autologous tolerogenic dendritic cells for rheumatoid and inflammatory arthritis. Ann Rheum Dis 76(1):227-234

154. Voigtlander C, Rossner S, Cierpka E, Theiner G, Wiethe C, Menges M, Schuler G, Lutz MB (2006) Dendritic cells matured with TNF can be further activated in vitro and after subcutaneous injection in vivo which converts their tolerogenicity into immunogenicity. J Immunother 29(4):407-415

155. Lim DS, Kang MS, Jeong JA, Bae YS (2009) Semi-mature DC are immunogenic and not tolerogenic when inoculated at a high dose in collagen-induced arthritis mice. Eur J Immunol 39(5):1334-1343

156. Ludewig B, Ochsenbein AF, Odermatt B, Paulin D, Hengartner H, Zinkernagel RM (2000) Immunotherapy with dendritic cells directed against tumor antigens shared with normal host cells results in severe autoimmune disease. J Exp Med 191(5):795-804 